\title{
Perspectives of Anaerobic Soil Disinfestation
}

J.G. Lamers, W.T. Runia, L.P.G. Molendijk and P.O. Bleeker

Applied Plant Research for Arable Farming and Field Production of Vegetables

Wageningen University and Research

P.O. Box 430, 8200 AK Lelystad

The Netherlands

Keywords: Verticillium dahliae, Fusarium oxysporum, biological soil disinfestation, Meloidogyne spp., Pratylenchus penetrans, weeds, Ralstonia solanacearum

\begin{abstract}
Biological soil disinfestation is an environmentally friendly method to disinfest soil. From now on we refer to it as anaerobic soil disinfestation (ASD). With ASD a green manure crop (40 t/ha) is homogeneously incorporated into the topsoil $(0-30 \mathrm{~cm})$ after which the field is lightly compacted and irrigated. Subsequently the field is mechanically covered with air tight virtually impermeable film (VIF) to restrict oxygen supply to the topsoil. The soil is left covered for six weeks in the summer. In this period anaerobic conditions develop rapidly in which toxic fermentation products are formed. These conditions are responsible for elimination of fungal and bacterial pathogens as well as parasitic nematodes, insects and weeds. In the Netherlands since 2004 anaerobic soil disinfestation (ASD) was applied on approximately 70 ha mainly for asparagus and strawberry runners production. When the asparagus crop was replanted ASD proved to be profitable for many years by controlling Fusarium oxysporum. Although highly effective against soilborne pathogens and pests ASD is not applied widely in the Netherlands due to the high costs of about $€ 4000$ per ha. Apart from the costs this technique needs special attention to prevent plastic damage. Moreover the mechanism behind ASD is not well defined which makes recommendations for growers complex. A new and promising development in ASD is the application of defined products on a basis of mixtures of carbon hydrates and proteins. The mechanism of ASD will be studied in the next few years with some of these products by measuring gases and fatty acids and microbial shifts in relation to efficacy. Chemical soil disinfestation with fumigants is restricted more and more and a non-chemical approach of soil disinfestation like ASD is urgently needed.
\end{abstract}

\section{INTRODUCTION}

Intensive crop rotations have increased the problems with soilborne diseases. Disease control with chemicals like fungicides, fumigants or methyl bromide is increasingly limited by environmental restrictions. For that reason there is much interest in non-chemical alternatives for soil disinfestation with natural products without harmful effects on the environment. Anaerobic soil disinfestation can meet the requirements to control all kinds of pests and diseases in soils in an environmental safe way.

Essentially anaerobic soil disinfestation is derived from soil flooding. Under water anaerobic conditions prevail in the soil and many pathogens are killed. Soil flooding however is restricted to flat areas with a low water infiltration rate underneath. By replacing the water by an air tight plastic film anaerobic conditions prevail over the whole soil profile under the film. In this way no rapid recolonization is expected as was the case in the top soil layer after soil flooding (Stover, 1955).

Anaerobic soil disinfestation (ASD) with incorporation of large amounts of fresh organic matter in soil followed by irrigation and then sealing off the soil with virtually impermeable film (VIF) is a method developed in the Netherlands. The method is based on the principle that under gastight plastic anaerobic conditions are created which convert organic material into other organic compounds. These compounds are supposed to be lethal to soilborne pathogens and pests at the concentrations realized. Moreover the lack 
of oxygen may support the efficacy (Blok et al., 2000). Also an increase in soil temperature and water content of the soil decrease the survival of for instance Fusarium oxysporum (Stover, 1954).

All aspects of anaerobic soil disinfestation with green manure are discussed in this paper.

\section{THE METHOD OF ANAEROBIC SOIL DISINFESTATION (ASD)}

The farmer starts growing a green manure in the field to be disinfested or produces the green manure in another field. The green manure is harvested in summer and incorporated with a rotary spading cultivator in conjunction with a pressure roller into the top soil layer of about $30 \mathrm{~cm}$. The amount of manure in this case should be 40 tonnes $/ \mathrm{ha}$. The compacted soil is irrigated with $25-50 \mathrm{~mm}$ of water. The next day a contractor spreads out the $3.5 \mathrm{~m}$ wide strips of VIF. One side of the film is glued to another film strip already fastened on the soil surface and the other side is dug into the soil with discs. Under anaerobic conditions toxic substances evolve from the manure, killing pathogens, pests and weeds. After four to six weeks the plastic may be removed from the land. The method is adjusted for control of replant disease in asparagus. Then 80 tonnes of green manure per ha are rotary tilled to a depth of $80 \mathrm{~cm}$ before plastic mulching.

Care must be taken that ASD is applied in a correct way. Of course the plastic should not be blown away when there is much wind. Perforation of the plastic by sharp lumps of soil, shells, straws or stems of woody plants should be prevented by smoothing out the surface. Incorporation of the organic manure should be in an early stage before the stems starts to lignify. Plastic damage by animals can be prevented by fencing of the plot. Birds should be scared off (Molendijk et al., 2008). Also a thicker plastic sheet may be used.

Crops to be incorporated may be all kind of fresh material grown on the spot or in other fields providing crops are no host plants for parasitic nematodes. On the contrary when plants are used as catch crops for certain nematode species two modes of action are combined. This is for instance the case with Tagetes patula which eliminates Pratylenchus species or with some glucosinolate containing Brassica crops resistant against beet cyst nematodes. In the latter case biofumigation is combined with ASD. Broccoli plants (Blok et al., 2000) or white mustard (Thanning and Gerhardson, 2001) however did not increase pathogen control. When rapidly fermentable material is replaced by slow deteriorating material like ripe composts then unsatisfactory results are obtained.

Initially plastic sheets were ensilage films of $0.12 \mathrm{~mm}$ thick PE. The oxygen permeability was about $1500 \mathrm{ml} / \mathrm{m}^{2} /$ day/bar. The use of three layer VIF plastic sheets of $0.035 \mathrm{~mm}$ thickness reduced the oxygen permeability to $240 \mathrm{ml} / \mathrm{m}^{2} /$ day $/$ bar and decreased survival of $V$. dahliae and $F$. oxysporum in three experiments (Lamers et al., 2004).

\section{THE ANAEROBIC PROCESS}

When VIF has been laid over the field the oxygen content of the soil decreases rapidly under $1 \%$ within a few hours and remains that low for seven weeks (Termorshuizen et al., 2000). The redox potential (Eh) of the soil decreases to low levels indicating high reducing soil conditions (Blok et al., 2000). First the oxygen in the soil is reduced, then with lowering of the redox potential nitrate and $\mathrm{Mn}^{4+}$ are reduced, followed by $\mathrm{Fe}^{3+}$ and sulfate. When the redox potential is less than $-200 \mathrm{mV}$ even methane gas can be formed after reduction of carbohydrates or $\mathrm{CO}_{2}$ (Reddy, 1987). Under anaerobic conditions also other gases like ammonia, hydrogen sulfide and nitrous oxide are created. Other fermentation products produced are fatty acids like (iso)butyric acid, maleic acid, (iso)valeric acid, acetic acid, lactic acid, citric acid and propionic acid. Ammonia is known to be lethal to root lesion nematode Pratylenchus penetrans (Min et al., 2007). Nematicidal effects of fatty acids have been demonstrated recently by several research groups (Abdel-Rahman et al., 2008; Mahran et al., 2008; Xiao et al., 2008).

The concept of biological soil disinfestation is also applicable to other disinfestation methods like biofumigation, solarization and flooding. Therefore in future 
we will use the term anaerobic soil disinfestation (ASD) instead of biological soil disinfestation. This name is more accurate concerning the anaerobic processes involved.

\section{EFFICACY}

\section{Against Pathogenic Fungi}

1. Fusarium oxysporum f.sp. asparagi. Blok et al. (2000) demonstrated that Fusarium oxysporum f.sp. asparagi inoculum samples were controlled to a level of $99 \%$ or more when artificially introduced in fields subjected to anaerobic soil disinfestation. In other experiments the level of control varied between 50 till $95 \%$ in bio assays with ASD treated field soil (Meijer en Lamers, 2004). When one year old asparagus plants were planted in untreated and ASD-treated fields $61 \%$ of roots were deceased in untreated plots after one year whereas in treated fields $14 \%$ of the roots were dead (Lamers et al., 2000). In a field experiment where Fusarium incidence in the soil decreased from 1.8 before ASD to 1.0 in treated soil on a scale from 0 (non-infected) to 3 (heavily infected) the asparagus crop developed slightly better in the first year and much better in later years (Lamers and Wilms, 2008). In the fifth and sixth year after the anaerobic soil disinfestation the yield was respectively 17 and 53\% higher than in untreated control fields. Fusarium is a slow killer of the asparagus plant and as causal agent for replant disease responsible for ending the asparagus harvest after six years in stead of ten years. In an experiment in Geel (Belgium) the ASD treatment reduced low infections in the layer $0-30 \mathrm{~cm}$ and $45-75 \mathrm{~cm}$ from 0.3 and 0.1 to 0.0 and 0.0 respectively (Lamers and Kanters, 2001). When the Fusarium contamination of the soil was minimal no negative effect of ASD was seen by two farmers indicating that anaerobic soil disinfestation is not harmful to the soil. One farmer had a replant soil with a reasonable contamination (bio assay 0.6). ASD decreased the contamination till 0.1. Five and six years after the anaerobic soil disinfestation the yield difference with the control field had increased 32 and $36 \%$ respectively (Lamers and Wilms, 2008).

2. Verticillium dahliae. In numerous experiments with strawberries the Verticillium dahliae contamination of the soil decreased with $75 \%$ (Wanten et al., 2005a), 100\% (Wanten et al., 2005b, c) and 99\% (Wanten et al., 2005d). In the latter experiment in clay soil strawberry yield after ASD had increased with 300\% (22.8 tonnes/ha versus 7.8 tonnes/ha). The control field had five microsclerotia/g of soil. The percentage diseased plants was at the end of the season $100 \%$ in the control fields and varied between 5 and $32 \%$ for the ASD fields (Wanten et al., 2005b, c, d). In experiments with trees Verticillium was reduced with $85 \%$ (Goud et al., 2003). Thanning and Gerhardson (2001) had a significant reduction of artificially buried $V$. dahliae samples in soil in four ASD trial fields of about $50 \%$.

Yield loss in a sensitive crop like strawberry is caused not only by Verticillium but also by Pratylenchus penetrans nematodes. Both pathogens interact with each other. As ASD also controls Pratylenchus the overall effect is bigger then when only one of the pathogens is controlled. Nevertheless when farmers control Pratylenchus with a Tagetes crop control of Verticillium by ASD is mostly not profitable in the modern cropping systems based on a short growing season with cold stored strawberry plants.

3. Rhizoctonia spp. Rhizoctonia solani AG3 is sensitive to ASD. The viability of the fungus is decreased with $90-100 \%$ (Blok et al., 2000). Rhizoctonia solani AG 2-2 IIIB seems to be sensitive in some experiments where it is not in other experiments. Villeneuve et al. (2004) reported good control of Rhizoctonia solani AG 4 and AG 2-2 and of Rhizoctonia fragariae. Rhizoctonia tuliparum was controlled for $94-100 \%$ in three experiments (Blok and Lamers, 2001). Rhizoctonia solani AG3 grown on perlite is used as test organism to measure efficacy of ASD in field experiments.

4. Sclerotinia sclerotiorum and Sclerotium cepivorum. Sclerotia of Sclerotinia were sensitive to ASD conditions as only 10-0\% survived (Blok and Lamers, 2001). Also Thanning and Gerhardson (2001) found a significant reduction of about $50 \%$ of viable sclerotia of $S$. sclerotiorum, but no reduction for the sclerotia of $S$. cepivorum. 


\section{Against Nematodes}

1. Pratylenchus spp. Pratylenchus penetrans is very sensitive for ASD and is controlled for $100 \%$ in one experiment (Blok and Lamers, 2001). Jansma et al., (2001) found an effective control in flower bulb culture. Pratylenchus fallax was reduced with $95-99 \%$ in experiments with trees (Goud et al., 2003).

2. Meloidogyne spp. The root-knot nematode $M$. fallax was controlled efficiently by ASD (Meijer and Lamers, 2004). M. chitwoodi nematodes can also be controlled by ASD effectively (Korthals, 2001).

3. Globodera spp. Efficacy of ASD against the potato cyst nematode Globodera pallida varied between 25 and 95\% (Meijer and Lamers, 2004). Spaull et al. (1992) noticed that the effect of an anaerobic atmosphere alone was less pronounced on survival of Globodera pallida than after flooding. However addition of organic amendment before flooding to increase hydrogen sulfide decreased survival of Globodera pallida more than flooding without amendments. Effects increased as temperatures increased within the range of 5 to $20^{\circ} \mathrm{C}$.

4. Trichodoridae. Artificially inoculation of soil with Paratrichodorus nematodes showed after ASD no or insufficient results against these free living nematodes. A naturally infested soil could be disinfested well with ASD (Meijer and Lamers, 2004). Paratrichodorus teres is reduced by ASD but remaining nematodes may still transmit tobacco rattle virus causing damage in potatoes (Hartsema, 2001).

5. Ditylenchus spp. The stem nematode Ditylenchus can be controlled by ASD (Meijer and Lamers, 2004).

\section{Against Bacteria}

1. Ralstonia solanacearum. Ralstonia solanacearum is a quarantine organism which is difficult to control. Messiha et al. (2007) proved that Ralstonia is effectively controlled by ASD. Also Blok (pers. commun.) found in one experiment a good control of brown rot caused by Ralstonia in potatoes.

\section{Against Weeds}

Creeping yellow fieldcress (Rorippa sylvestris) had disappeared after ASD (Jansma et al., 2001). However the total weed population seemed not to be effected one or more years after ASD in 7 experiments (Zeeland et al., 2004). In four out of seven experiments the presence of the plant common chickweed (Stellaria media) was significantly reduced. When the fresh organic manure is contaminated with many (grass) weed seeds then more weeds can be observed after ASD. In contrast ASD can be used to control weeds that survive on root stocks. In laboratory and field experiments the survival of snow-thistle (Sonchus arvensis), hedge bindweed (Calysstegia sepium), coltsfoot (Tussilago farfara) en couch grass (Agropyron repens) were strongly reduced (Zeeland and Weide, 2005). On farms with a big problem with weed that survives on rootstocks ASD may be considered. Sometimes organic farms have such problems. On farm research in 2007 and 2008 showed that ASD can reduce the survival of snow-thistle (Sonchus arvensis) very well (Bleeker, 2008).

\section{Long-Term Efficacy}

Soil suppressiveness against pests and diseases is not changed by ASD. $F$. oxysporum lesions developed equally on roots from asparagus on ASD and control soil after introduction of the pathogen (Blok et al., 2000). Also the soil suppressiveness for Meloidogyne was not changed (Kok, pers. commun.). Fungal antagonists like Verticillium biguttatum however seem to be sensitive to ASD. The shift in soil microflora does not necessarily imply a shift in suppressiveness. As $F$. oxysporum may reduce the life time of an asparagus replant from ten to five years the most striking results of ASD are obtained after five years when plants in the untreated control plots decay whereas plants in ASD treated soil still produce a crop (Lamers and Wilms, 2008). The same applies for Verticillium dahliae in trees. The degree of incidence in ASD treated fields remained at a 
low stable level for four years and the trees were not affected by the fungal pathogen (Goud et al., 2003). In stead $V$. dahliae incidence of the untreated soil increased.

\section{PROFITABILITY}

Costs of ASD are high. Only the costs for sealing of the soil with VIF strips glued together are already as high as $€ 3.000$ per ha. Besides that there are costs for growing or buying the green manure, for irrigation and discharge of the plastic foil. Moreover a cash crop cannot be grown that year. Because of this ASD is at the moment only profitable in high yielding cash crops like asparagus production crops, strawberry runners production and in tree nurseries.

\section{RESEARCH TOPICS}

Although highly effective ASD is implemented on a small scale due to several factors. Apart from the costs one of the most important factors however is the lack of fundamental information about the mode of action of ASD which hampers the progress into an effective reliable soil disinfestation method for arable crops and field vegetables as well. More data should become available on:

- which compounds at what concentrations are responsible for the efficacy;

- for how long anaerobic conditions should prevail related to soil temperature in order to specify the recommendations for application.

For introduction of ASD in rotations of arable crops and other field vegetables or protected cultivation several questions have to be answered. Apart from knowledge about effective compounds and soil temperature other factors like $\mathrm{pH}$, soil fertilizer status, soil organic matter, soil humidity and type of organic matter to be incorporated need to be studied in relation to efficacy. This will promote an implementation on (inter)national scale.

In 2009 a new research program has started by Applied Plant Research of Wageningen University \& Research to optimize ASD. Several defined products on a basis of mixtures of carbon hydrates and proteins with varying $\mathrm{C} / \mathrm{N}$ ratio are incorporated in the soil instead of fresh grass. The mechanism of ASD will be studied by measuring oxygen, greenhouse gases like methane, ammonia and nitrous oxide and fatty acids during the process in relation to efficacy against root lesion nematodes Pratylenchus penetrans, potato cyst nematodes Globodera pallida and Verticillium dahliae in sandy soil as well as in organic soil. Microbial shifts will be studied when promising products are selected for field application in order to understand the mechanism behind anaerobic soil disinfestation.

\section{CONCLUDING REMARKS}

The method of anaerobic soil disinfestation is applied successfully in the Netherlands mainly in asparagus production crops and in fields allocated for strawberry runner production. These crops are grown on sandy soils with low organic matter content. ASD with grass as organic source has proven to be effective against parasitic nematodes like Pratylenchus spp. and Meloidogyne spp. as well as against fungal soilborne pathogens like Fusarium oxysporum spp. and Verticillium dahliae and can be regarded as an effective non-chemical method for soil disinfestation. Because of the high costs ASD is profitable at the moment only in high value crops like asparagus and strawberry and in tree nurseries. New developments in ASD should lead to wider application of a profitable ASD technique with predictable efficacy under various soil conditions.

\section{Literature Cited}

Bleeker, P.O. 2008. Onderzoek naar de beheersing van meerjarige onkruiden. PPO-AGV, Lelystad, the Netherlands, report 32500313, p.25.

Abdel-Rahman, F.H., Clark, S. and Saleh, M.A. 2008. Natural organic compounds as alternative to methyl bromide for nematodes control. J. Environm. Sci and Health Part B, Pesticides, Food Contaminants, and Agricultural Wastes 43(8):680-685. 
Blok, W. and Lamers, J. 2001. Biologische grondontsmetting werkt. Groente en Fruit, the Netherlands, Feb. 9, vakdeel vollegrondsgroenten: 4-7.

Blok, W.J., Lamers, J.G., Termorshuizen, A.J. and Bollen, G.J. 2000. Control of soilborne plant pathogens by incorporating fresh organic amendments followed by tarping. Phytopathology 90:253-259.

Goud, J.C., A.J. Termorshuizen, W.J. Blok and van Bruggen, A.H.C. 2003. Long-term effect of biological soil disinfestation on Verticillium wilt. Plant Disease 88:688-694.

Jansma, J.E., Vlaming, E.A.C., Boer, M. de and Blok, W. 2001. Biologische grondontsmetting. Ekoland, the Netherlands 21:26-27.

Lamers, J.G., Blok, W.J. Coenen, G.C.M., Molendijk, L.P.G. and Termorshuizen, A.J. 1997. Een nieuwe aanpak van bodemschimmels en aaltjes. PAV-Bulletin Lelystad, the Netherlands, vollegrondsgroenten: 2-4.

Lamers, J.G., Blok, W.J. and Termorshuizen, A.J. 2000. Biological soil disinfestation to control Fusarium oxysporum f.sp. asparagi in Dutch asparagus fields. In: Abstracts of Symposium on chemical and non-chemical soil and substrate disinfestation, Torino, Italy, p. 15.

Lamers, J. and Kanters, F. 2001. Bij herinplant grond biologisch ontsmetten. LTO groeiservice, the Netherlands, gewasnieuws asperge 4:3.

Lamers, J., Wanten, P., Blok, W. 2004. Biological soil disinfestation: a safe and effective approach for controlling soilborne pests and diseases. Agroindustria 3:289-291.

Lamers, J. and Wilms, J. 2008. De lange termijn werking van biologische grondontsmetting. Biologische grondontsmetting doet de opbrengst ieder jaar stijgen tot wel 100\% na herinplant van asperges. PPO-AGV report 3252045600, Lelystad, the Netherlands, p.27.

Mahran, A., Tenuta, M., Hanson, M.L. and Daayf, F. 2008. Mortality of Pratylenchus penetrans by volatile fatty acids from liquid hog manure. J. of Nematology 40:119126.

Meijer, B. and Lamers, J. 2004. Biologische grondontsmetting: bestrijding van bodemziekten voor een gezonde bodem. PPO, Lelystad, the Netherlands, Publication 415:26.

Messiha, N.A.S., van Diepeningen, A.D., Wenneker, M., van Beuningen, A.R., Janse, J.D., Coenen, T.G.C., Termorshuizen, A.J., van Bruggen, A.H.C. and Blok, W.J. 2007. Biological Soil Disinfestation (BSD), a new control method for potato brown rot, caused by Ralstonia solanacearum race 3 biovar 2. Europ. J. Plant Pathol. 117:403-415.

Min, Y.Y., Sato, E., Shirakashi, T., Wada, S., Toyota, K. and Watanabe, A. 2007. Suppressive effect of anaerobically digested slurry on the root lesion nematode Pratylenchus penetrans and its potential mechanisms. Japan. J. of Nematology 37:93100.

Molendijk, L., Runia, W., van der Waal, B., Lamers, J., Korthals, G. 2008. Studie naar perspectieven voor biologische grondontsmetting. PPO-AGV, Lelystad, the Netherlands, report 3250084300, p.48.

Reddy, K.R. 1987. The effect of flooding on physical, chemical and microbiological properties of histosols. p.7-22. In: G.H. Snyder, Agricultural flooding of organic soils, chapter 2, University of Florida.

Runia, W.T., van Beers, T.G., Brommer, E., Kok, C.J. and Molendijk, L.P.G. 2006. Resultaten van het HPA project Inventarisatie bestrijdingsmethoden. Biologische grondontsmetting; anaërobie, PPO-AGV Lelystad, the Netherlands, report 3250037500 , p. $20-21$.

Spaull, A.M., Trudgill, D.L. and Batey, T. 1992. Effects of anaerobiosis on the survival of Globodera pallida and possibilities for control. Nematologica 38:88-97.

Stover, R.H. 1954. Flood-fallowing for eradication of Fusarium oxysporum f. cubense: II Some factors involved in fungus survival. Soil Science 77:401-414.

Stover, R.H. 1955. Flood-fallowing for eradication of Fusarium oxysporum f. cubense: III Effect of oxygen on fungus survival. Soil Science 80:397-412. 
Termorshuizen, A.J., Blok, W.J. and Lamers, J.G. 2000. Biological soil disinfestation to control Verticillium dahliae by incorporation of fresh organic material followed by plastic mulching. p.328-331. In: E.C. Tjamos et al., Advances in Verticillium research and disease management, APS Press St Paul, Minnesota.

Thanning, C. and Gerhardson, B. 2001. Reduced sclerotial soil-longevity by whole-crop amendment and plastic covering. Journal of Plant Diseases and Protection 108:143151.

Wanten, P., Lamers, J., Evenhuis, A. and Meijer, H. 2005a. Biologische grondontsmetting, BPO 1999-2001. PPO-AGV report 5234477, Lelystad, the Netherlands, p.19.

Wanten, P., Lamers, J. and Wilms, J. 2005b. Biologische grondontsmetting, Meterik 2001-2003. PPO-AGV report 520032, Lelystad, the Netherlands, p.25.

Wanten, P., Lamers, J., Wilms, J. and Van den Berg, W. 2005c. Biologische grondontsmetting, Meterik 2002-2004. PPO-AGV report 520032, Lelystad, the Netherlands, p.24.

Wanten, P., Lamers, J. and Van den Berg W. 2005d. Biologische grondontsmetting, Randwijk 2001-2003. PPO-AGV report 520032, Lelystad, the Netherlands, p.21.

Villeneuve, F., Raynal-Lacroix, C., Lempire, C. and Maignien, G. 2004. Possibility of using biofumigation in vegetable crops for controlling soilborne pathogens. Book of abstracts, First International Symposium on Biofumigation: a possible alternative to methyl bromide?, ISCI, Firenze, Italia, p.81-82.

Xiao, J., Chen, S, Zhu, J. and Ruan, W. 2008. Effect of liquid swine manure on hatch and viability of Heterodera glycines. J. of Nematology 40:152-160.

Zeeland, M.G. van, Weide, R.Y. van der 2006. Onkruidbestrijding door afdekking. Ekoland, the Netherlands 1:22-23.

Zeeland, M.G. van, Weide, R.Y. van der, Groeneveld, M.W. Scheepens, P.C., and Uffing, A.J.M. 2004. Effecten van biologische grondontsmetting op de onkruiddruk. PPO, Lelystad, the Netherlands, report 520274, p.20. 
